\title{
Piata palisade grass deferred with two distinct initial heights: luminous environment and tillering dynamics
}

\author{
Braulio Maia de Lana Sousa ${ }^{1}$, Manoel Eduardo Rozalino Santos², Hélio Henrique Vilela1, \\ Márcia Cristina Teixeira da Silveira ${ }^{3}$, Gabriel de Oliveira Rocha ${ }^{1}$, Cássia Aparecida Soares \\ Freitas ${ }^{1}$, Natascha Almeida Marques da Silva ${ }^{2}$, Domicio do Nascimento Júnior ${ }^{1}$
}

\footnotetext{
${ }^{1}$ Departamento de Zootecnia - UFV, Viçosa, MG, Brazil.

2 Faculdade de Medicina Veterinária - UFU, Uberlândia, MG, Brazil.

${ }^{3}$ Embrapa Pecuária Sul, Bagé, RS, Brazil.
}

\begin{abstract}
The study was carried out between March 1st and July 1st, 2011, in order to evaluate the tillering pattern of the deferred Piata palisade grass (Brachiaria brizantha cv. Piata). Three sward heights were evaluated in the beginning of the period of deferment: lower $(20 \mathrm{~cm})$, medium $(30 \mathrm{~cm})$ and higher $(40 \mathrm{~cm})$. The experimental design was of completely randomized blocks with three replications. The Piata palisade grass deferred with low initial height presented lower leaf area index, lower light interception and higher leaf angle in relation to the ones deferred with medium and high heights. The advance in the period of deferment increased the leaf area index and the light interception by the sward, in a way that the highest values were recorded in the periods from 91 and 120 days. The leaf angle reduced linearly with the advance in the period of deferment. For basal and aerial tillers, the rates of appearance, mortality and survival of tillers, as well as the balance between appearance and mortality, and the tiller density stability index were not affected by the initial height of the sward. The stability index of the tiller density was lower in the period from 1 to 30 days of deferment in relation to the periods from 31 to 60 , from 61 to 90 and from 91 to 120 days. The variation of the initial height of the Piata palisade grass does not influence the tiller density dynamics during the period of deferment. The reduction of the initial height of the Piata palisade grass improves the luminous environment inside the sward, but it does not stimulate the grass tillering during the period of deferment.
\end{abstract}

Key Words: Brachiaria brizantha, deferred grazing, ecophysiology, tiller

\section{Introduction}

The deferment of the pasture is a relatively simple and low-cost strategy of management, which enables the storage of forage to be used in the most critical months of the year in forage resources. This contributes to the balance between supply and demand of forage in the production system, which is a basic premise of the animal production in grasslands.

In this context, the Piata palisade grass (Brachiaria brizantha var. Piata), which was launched by EMBRAPA Gado de Corte in 2006 (Embrapa, 2007) in Brazil, may be adequate for the deferred grazing because it presents a relatively slender stem, medium natural height, and flowering period preceding the one in which the pastures are normally kept deferred in the Southeast and Midwest of Brazil, among other characteristics.

During the period of deferment, there is reduction of the total number of tillers, mainly of the ones in vegetative state; however, there is an increment of the tiller density of reproductive and dead tillers on the pasture
(Santos et al., 2009; Santos et al., 2010). This determines a deferred pasture with structure not very favorable to animal intake and performance.

To circumvent the deleterious effects of the period of deferment on the plant tillering, the reduction of the height of the sward is recommended in the beginning of this period (Santos et al., 2009). The premise for this recommendation is that higher defoliation results in more penetration of light inside the sward, which is a favorable condition for the stimulus to the tillering of forage plants. However, in deferred grasslands, this benefit has not been scientifically confirmed yet. In addition to this, there is a possibility that the restrictive weather conditions of the plant at the end of the fall and during the winter, periods in which the pasture keeps normally deferred, minimize or block all the possible benefits of the reduction of the pasture height on its tillering, especially if the period of deferment is excessively long.

Thus, this study was carried out with the objective of verifying if a lower initial sward height improves the luminous environment and really stimulates its tillering during the period of deferment. Among other characteristics, 
the rates of appearance, of mortality, and of flowering of tillers of Piata palisade grass deferred with three initial heights were evaluated during the period of deferment.

\section{Material and Methods}

The experiment was conducted from March 1st to July 1st, 2011, in the forage sector of the Departamento de Zootecnia, at Universidade Federal de Viçosa (UFV), located in Viçosa, Minas Gerais state, Brazil. The approximate geographic coordinates of the experiment location are $20^{\circ} 45^{\prime}$ south latitude and $42^{\circ} 51^{\prime}$ west longitude, and the altitude is $651 \mathrm{~m}$. An area with Piata palisade grass of approximately $100 \mathrm{~m}^{2}$, established in 2009, on RedYellow clayey Latosol (Embrapa, 2006) was used.

According to Köppen (1948), the climate of the region of Viçosa is the Cwa type, with annual rainfall around $1,340 \mathrm{~mm}$ and average relative air humidity of $80 \%$. Climatic data recorded during the experimental period were obtained at the meteorological station of the Departamento de Engenharia Agrícola of UFV, located about 1,000 m from the experimental area (Table 1).

According to the results of the chemical analysis performed at the beginning of the experimental period, on the $0-20-\mathrm{cm}$ layer, the soil presented the following characteristics: $\mathrm{pH}$ in $\mathrm{H}_{2} \mathrm{O}: 5.50$; $\mathrm{P}$ (Mehlich-1): $1.40 \mathrm{mg} /$ $\mathrm{dm}^{3}$ and $\mathrm{K}: 36.00 \mathrm{mg} / \mathrm{dm}^{3} ; \mathrm{Ca}^{2+}: 2.10 \mathrm{cmol}_{\mathrm{c}} / \mathrm{dm}^{3} ; \mathrm{Mg}^{2+}$ : $0.70 \mathrm{cmol}_{\mathrm{c}} / \mathrm{dm}^{3}$ and $\mathrm{Al}^{3+}: 0.00 \mathrm{cmol}_{\mathrm{c}} / \mathrm{dm}^{3}(\mathrm{KCl} 1 \mathrm{~mol} / \mathrm{L})$ and $\mathrm{V}: 43.0 \%$. Based on these results, liming was not done. The maintenance fertilization was performed using nitrogen in the form of urea at $75 \mathrm{~kg} / \mathrm{ha}$, phosphorus in the form of single superphosphate at $60 \mathrm{~kg} / \mathrm{ha}$ and potassium in the form of potassium chlorite at $60 \mathrm{~kg} / \mathrm{ha}$. This fertilization was performed at the beginning of the deferment period (March 1st, 2011), in a single dose in the end of the afternoon, as the one performed by Santos et al. (2009).

Only on the first day of the experimental period and after the fertilization, the area was manually wet, with the use of a plastic hose, to avoid the humidity of the soil and

Table 1 - Monthly means of the minimum, the average, and the maximum daily temperature, total monthly rainfall, and total monthly evaporation from March to July in 2011

\begin{tabular}{lcccrc}
\hline Month & $\begin{array}{c}\text { Minimum } \\
\text { temperature } \\
\left({ }^{\circ} \mathrm{C}\right)\end{array}$ & $\begin{array}{c}\text { Average } \\
\text { temperature } \\
\left({ }^{\circ} \mathrm{C}\right)\end{array}$ & $\begin{array}{c}\text { Maximum } \\
\text { temperature } \\
\left({ }^{\circ} \mathrm{C}\right)\end{array}$ & $\begin{array}{c}\text { Rainfall } \\
(\mathrm{mm})\end{array}$ & $\begin{array}{c}\text { Evaporation } \\
(\mathrm{mm})\end{array}$ \\
\hline March & 19.1 & 22.1 & 27.5 & 284.4 & 53.4 \\
April & 17.3 & 20.8 & 26.9 & 56.6 & 53.6 \\
May & 13.7 & 17.6 & 24.7 & 2.6 & 57.7 \\
June & 11.5 & 15.9 & 23.1 & 23.0 & 64.4 \\
July & 9.9 & 15.6 & 24.1 & 0.0 & 60.9 \\
\hline
\end{tabular}

to increase the efficiency of the fertilization. The objective was to simulate a rainfall of $5 \mathrm{~mm}$. This strategy was also employed to simulate what normally occurs in practice, i.e., fertilizing the grasslands in the beginning of the period of deferment and after the rain occurrence when the soil still presents satisfactory humidity.

Three initial heights of the sward at the beginning of the deferment period were evaluated: low $(20 \mathrm{~cm})$, medium $(30 \mathrm{~cm})$ and high $(40 \mathrm{~cm})$. The design was of complete randomized blocks, with three replications. The establishment of the sward heights was performed with a mechanical cut using a mower. The criterion utilized for the definition of the blocks was the variation of the relief of the experimental area. Each block was subdivided following the existing relief variation of the experimental area, with the aid of wood stakes, in three plots $\left(8.0 \mathrm{~m}^{2}\right)$, to which the initial heights of deferment were raffled.

The evaluations were performed at the beginning of the experimental period (March 1st, 2011), every 30 days, until the last day of deferment (July 1st, 2011), a date that was considered appropriate for the beginning of the period of using the deferred grasslands in the region of Viçosa. The Piata palisade grass remained deferred for 120 days.

The measurement of the light interception by the sward, of the leaf area index and of the leaf angle was performed by utilizing a Plant Canopy Analyzer LAI 2000 (LI-COR ${ }^{\circledR}$ ) in two random spots per experimental unit. In each spot, one reading above the sward and five on the soil surface were taken.

The evaluations of the tillering pattern were performed within a PVC ring of $30 \mathrm{~cm}$ of diameter per experimental unit, which was stuck to the ground by metallic staples and placed at representative points of the average pasture height. At the beginning of the experimental period (March 1st, 2011), all tillers within the squares were counted and tagged with a plastic-coated wire of a certain color. At every 30 days, all tagged tillers were counted once more; new tillers were tagged with a different color form the previous tagging; the wires of dead tillers were removed. In each counting and tagging procedure, the tillers were differentiated in relation to their origin of development in aerial and basal tillers. Thus, it was possible to estimate the tiller population of all generations, and to calculate the rates of appearance [(flowered tillers/total live tillers at the previous tagging $) \times 100]$, mortality [(dead tillers/total live tillers at the previous tagging $) \times 100$ ], survival $(100-$ tiller mortality rate) and tiller flowering [(flowered tillers/total live tillers at the previous tagging $) \times 100]$, the balance between tiller appearance and mortality (tiller appearance - mortality rates) and the tiller population stability index 
[tiller survival rate $\times(1+$ tiller appearance rate $)]$, for basal and aerial tillers.

The data were organized in periods: from 1 to 30,31 to 60,61 to 90 and 91 to 120 days. The data analysis was performed using the statistical package SAEG (Sistema de Análises Estatísticas e Genéticas, version 8.1). All sets of data were tested to ensure that the ANOVA basic prerogatives were met, and when necessary, data were transformed. Thus, the leaf angle and the balance between tiller appearance and mortality had their data transformed into base 10 logarithm to perform the variance analysis. However, to present the results, the means of the nontransformed values were used. The rates of appearance and of flowering of tillers and the stability index of aerial and basal tillers, even transformed, did not meet the basic assumptions of the variance analysis, hence these rates were analyzed by the nonparametric statistics.

The values of the leaf area index, of the light interception, and of the leaf angle were regularly measured during the period of deferment, and, therefore, their values represented the condition of the pastures on the days of their measurements, which occurred on March 1st, April 1st, May 1st, June 1st, and July 1st, 2011. Thus, for these characteristics, the period of deferment was considered a quantitative factor, whose five levels were 1, 30, 60, 90 and 120 days. In this case, regression analysis was performed, considering models that best fitted the data. On the other hand, for the descriptive characteristics of the tillering dynamics, their values cannot be considered regular, since they were obtained in sub-periods of 30 days throughout the total period of deferment of the pastures. Because of that, the period of deferment was considered a qualitative factor, whose levels were the periods from 1 to 30,31 to 60,61 to 90 and 91 to 120 days. Therefore, the comparison among the levels of this factor, as well as the "initial sward height factor", was performed by Student-Newman-Keuls's test. The level of significance of $5 \%$ probability of occurrence of the type I error was adopted.

\section{Results}

The variables analyzed were not influenced by the interaction between initial height of the sward and the period of deferment $(\mathrm{P}>0.05)$. The leaf area index, the light interception, and the leaf angle were influenced by the initial height of the sward $(\mathrm{P}<0.05)$.

The Piata palisade grass deferred with low initial height presented lower $(\mathrm{P}<0.05)$ leaf area index and light interception in relation to the one deferred with medium and high initial height. However, the deferred Piata palisade grass with low initial height presented higher $(\mathrm{P}<0.05)$ leaf angle relatively to those deferred with medium and high initial heights (Table 2).

The leaf area index and the light interception were quadratically influenced $(\mathrm{P}<0.05)$, and the leaf angle was influenced linearly and negatively by the period of deferment (Table 3). The increase in the period of deferment raised the leaf area index and the light interception by the sward until the points of maximum value corresponding to 109 and 85 days respectively.

Table 2 - Structural characteristics of Piata palisade grass deferred with three initial heights

\begin{tabular}{lccccc}
\hline \multirow{2}{*}{ Characteristics } & \multicolumn{3}{c}{ Initial deferment height } & \multirow{2}{*}{ P value } & CV $(\%)$ \\
\cline { 2 - 4 } & Low $(20 \mathrm{~cm})$ & Medium $(30 \mathrm{~cm})$ & High $(40 \mathrm{~cm})$ & & 0.0003 \\
Leaf area index & $4.09 \mathrm{~b}$ & $5.06 \mathrm{a}$ & $5.25 \mathrm{a}$ & 0.0131 & 9.89 \\
Light interception (\%) & $92.8 \mathrm{~b}$ & $97.2 \mathrm{a}$ & $97.7 \mathrm{a}$ & 0.0165 & 10.20 \\
Leaf angle (degrees)* & $45.3 \mathrm{a}$ & $41.9 \mathrm{~b}$ & $42.6 \mathrm{~b}$ & & \\
\hline
\end{tabular}

$\mathrm{CV}$ - coefficient of variation.

* Variance analysis performed in transformed data (base 10 logarithm).

Means in the row followed by different letters are different by Student-Newman-Keuls'test $(\mathrm{P}<0.05)$.

Table 3 - Structural characteristics of the Piata palisade grass during the period of deferment

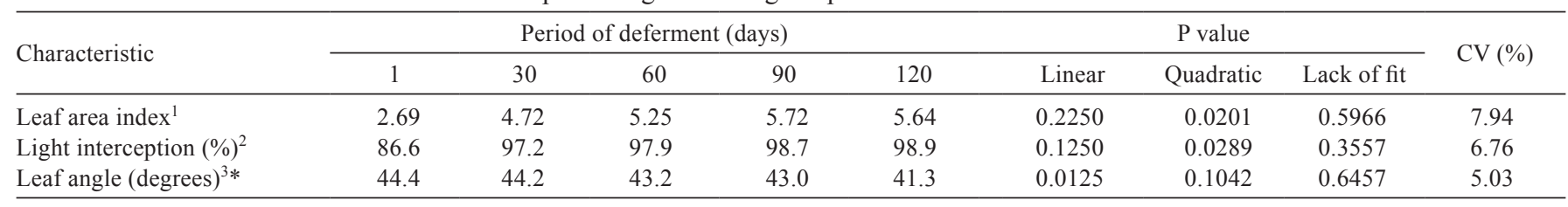

$\mathrm{CV}$ - coefficient of variation.

${ }^{1} \hat{Y}=2.7569+0.0652 X-0.0003 X^{2}\left(R^{2}=0.97\right)$.

${ }^{2} \hat{Y}=87.504+0.2892 X-0.0017 X^{2}+\left(R^{2}=0.90\right)$.

${ }^{3} \hat{\mathrm{Y}}=44.75-0.025 \mathrm{X}\left(\mathrm{r}^{2}=0.91\right)$.

* Variance analysis performed in transformed data (base 10 logarithm). 
The basal and aerial appearance rates were not affected by the initial height of the sward $(\mathrm{P}>0.05)$, presenting, on average, 26.71 and 106.33 tillers/100 tillers.30 days, respectively (Table 4 ).

However, the basal and aerial tiller appearance rates were influenced by the period of deferment $(\mathrm{P}<0.05)$. From 1 to 30 days, the deferred Piata palisade grass presented higher basal tiller appearance rate in relation to the periods from 31 to 60,61 to 90 and 91 to 120 days. For aerial tillers, the tiller appearance rate was higher from 1 to 30 , intermediate from 31 to 60 , and lower from 61 to 90 and 91 to 120 days (Table 5).

The mortality rate of basal and aerial tillers did not vary with the initial height of the sward $(\mathrm{P}>0.05)$; they were, on average, 16.36 and 18.82 tillers/100tillers.30 days, respectively (Table 4 ). The mortality rate of basal tillers was not influenced by the period of deferment $(\mathrm{P}>0.05)$ either. Nevertheless, in the aerial tillers, this variable was affected by the period of deferment $(\mathrm{P}<0.05)$, with higher value in the period from 31 to 60 days and from 91 to 120 days, intermediate from 1 to 30 days, and lower value from 61 to 90 days (Table 5).

The balance between the appearance and mortality of basal and aerial tillers was not influenced by the initial height of the sward $(\mathrm{P}>0.05)$, presenting, on average, 10.35 and 87.51 tillers/100 tillers.30 days, respectively (Table 4). However, the balance between the appearance and mortality of basal and aerial tillers varied according to the period of deferment $(\mathrm{P}>0.05)$. For basal and aerial tillers, the Piata palisade grass deferred from 1 to 30 days presented higher value in relation to the other periods (Table 5).

The survival rate of basal and aerial tillers was not influenced by the initial height of the sward $(\mathrm{P}>0.05)$; it was, on average, 83.64 and 81.18 tillers/100 tillers.30 days, respectively (Table 4 ). The survival rate of basal tillers was also not influenced by the period of deferment $(\mathrm{P}>0.05)$. Nevertheless, in the aerial tillers, this variable was higher in the Piata palisade grass deferred from 61 to 90 days, intermediate in that deferred from 1 to 30 days, and lower in

Table 4 - Descriptive characteristics of the tiller density of the deferred Piata palisade grass

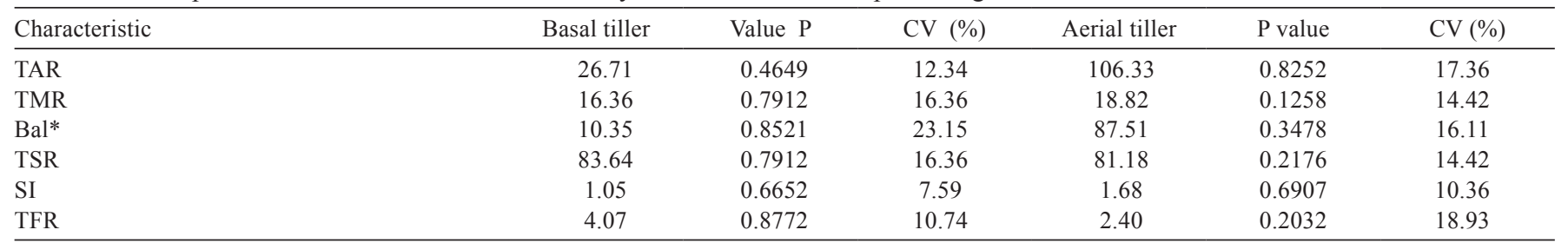

TAR - tiller appearance rate (tiller/100 tillers.30 days); TMR - tiller mortality rate (tiller/100 tillers.30 days); Bal - balance between tiller appearance and mortality (tiller/100 tillers.30 days); TSR - tiller survival rate (tiller/100 tillers.30 days); SI - stability index of tiller density; TFR - tiller flowering rate (tiller/100 tillers.30 days); CV - coefficient of variation.

* Variance analysis performed in transformed data (base 10 logarithm).

Table 5 - Descriptive characteristics of the tiller density dynamics of the Piata palisade grass during the period of deferment

\begin{tabular}{|c|c|c|c|c|c|c|}
\hline \multirow{2}{*}{ Characteristic } & \multicolumn{4}{|c|}{ Period of deferment (day) } & \multirow{2}{*}{$P$ value } & \multirow{2}{*}{$\mathrm{CV}(\%)$} \\
\hline & 1 to 30 & 31 to 60 & 61 to 90 & 91 to 120 & & \\
\hline \multicolumn{7}{|c|}{ Basal tiller } \\
\hline TMR & 19.67 & 12.88 & 17.23 & 15.67 & 0.3880 & 10.11 \\
\hline $\mathrm{Ba}^{*}$ & $83.32 \mathrm{a}$ & $-10.44 b$ & $-16.63 b$ & $-14.86 b$ & 0.2267 & 7.98 \\
\hline TSR & 80.33 & 83.13 & 82.77 & 84.33 & 0.3880 & 10.11 \\
\hline \multicolumn{7}{|c|}{ Aerial tiller } \\
\hline TAR & $395.11 \mathrm{a}$ & $24.41 \mathrm{ab}$ & $2.14 \mathrm{~b}$ & $3.67 \mathrm{~b}$ & 0.0112 & 18.56 \\
\hline TMR & $15.67 \mathrm{ab}$ & $27.75 a$ & $8.19 b$ & $23.67 \mathrm{a}$ & 0.0001 & 22.22 \\
\hline $\mathrm{Ba}^{*}$ & $379.44 a$ & $-3.34 b$ & $-6.05 b$ & $-20.00 b$ & 0.0321 & 28.59 \\
\hline TSR & $84.33 \mathrm{ab}$ & $72.25 \mathrm{~b}$ & $91.81 \mathrm{a}$ & $76.33 b$ & 0.0112 & 22.22 \\
\hline SI & $4.11 \mathrm{a}$ & $0.90 \mathrm{~b}$ & $0.94 \mathrm{~b}$ & $0.79 \mathrm{~b}$ & 0.0003 & 13.41 \\
\hline
\end{tabular}

TAR - tiller appearance rate (tiller/100 tillers.30 days); TMR - tiller mortality rate (tiller/100 tillers.30 days); Bal - balance between tiller appearance and mortality (tiller/100 tillers.30 days); TSR - tiller survival rate (tiller/100 tillers.30 days); SI - stability index of tiller density; TFR - tiller flowering rate (tiller/100 tillers.30 days); CV - coefficient of variation. $*$ Variance analysis performed in transformed data (base 10 logarithm); Means in the row followed by different letters are different by Student-Newman-Keuls's test $\mathrm{P}<0.05$ ). 
the Piata palisade grass deferred from 31 to 60 and 91 to 120 days (Table 5).

The stability index of basal and aerial tiller density was not affected by the initial height of deferment $(\mathrm{P}>0.05)$, presenting, on average, 1.05 and 1.68 respectively (Table 4 ). However, the stability index of the basal and aerial tillers was influenced by the period of deferment $(\mathrm{P}>0.05)$. The Piata palisade grass deferred from 1 to 30 days presented higher value in relation to the ones deferred from 31 to 60,61 to 90 , and 91 to 120 days (Table 5).

The flowering rate of basal and aerial tillers was not influenced by the initial deferment height $(\mathrm{P}>0.05)$ : on average, 4.07 and 2.40 tillers $/ 100$ tillers.30 days, respectively (Table 4). The flowering rate of aerial tillers was also not affected by the period of deferment $(\mathrm{P}>0.05)$. Nevertheless, this variable was influenced by the period of deferment of basal tillers ( $\mathrm{P}>0.05$ ). Higher value was recorded in the Piata palisade grass deferred from 1 to 30 days, intermediate in the one deferred from 31 to 60 days, and lower in the Piata palisade grass deferred from 61 to 90 and 91 to 120 days (Table 5).

\section{Discussion}

The leaf area index and the light interception by the sward increased quadratically with the advance of the period of deferment, with maximum values at 109 and 85 days, respectively (Table 3 ). As the plant grows and recovers its leaf area, the intraspecific competition for light raises progressively, a fact that is characterized by the elevation of the leaf area index and the light interception by the sward. However, in a more advanced stage, the higher competition between the tillers decreases the quantity and the quality of the light that penetrates the sward, which increases the shading at the base of the tiller and, consequently, accelerates the leaf senescence of the plants (Bircham \& Hodgson, 1983).

Despite the increase in the leaf senescence, the leaf area index keeps initially increasing because the first leaves to die are the ones that are nearer the ground, which present lower length in relation the new ones (Hodgson, 1990). As an adaptive response to the intense competition for light, the plant starts to invest in elongation of internodes as an attempt of allocating its leaves at the top of the sward (Da Silva, 2004). This increases the distance to be covered by the plant inside the pseudo stem, which raises the length of the leaf blade of the new emerging leaves (Lemaire \& Chapman, 1996; Duru \& Ducrocq, 2000).

Nevertheless, in more advanced stages of sward development, in which there is an elevated intraspecific competition for light, the stem elongation occurs concomitantly to the elevation of the apical meristem. This fact reduces the distance covered by the leaf inside the pseudo stem again (Lemaire \& Chapman, 1996; Duru \& Ducrocq, 2000). At this moment, the senescent leaves get equal or superior size in relation to the ones in expansion, which reduces the leaf area index of the Piata palisade grass in longer periods of deferment.

The leaf angle reduced linearly with the advance of the period of deferment (Table 3), due to the enlargement in the leaf blades. The higher weight of the leaf blade promotes a more horizontal disposition (lower leaf angle) (Bernardes, 1987).

The increase in the leaf area index causes alteration in the luminous environment inside the sward, which starts to be characterized by lower light penetration, as well as lower red:far red light ratio, which contributes to the decrease in the appearance rate of new tillers (Deregibus et al., 1983). In fact, at 30 days of regrowth, the Piata palisade grass presented elevated intraspecific competition for light, a fact characterized by the elevated level of light interception (97.2\%) (Table 2). This fact explains the drastic reduction in the appearance rate of basal and aerial tillers in the period from 31 to 60 days in comparison with the period from 1 to 30 days. The lowest incidence of light inside the sward reduces the differentiation of axillary buds which give origin to new tillers (Matthew et al., 2000).

On the pastures under adequate management, there is a dynamic and harmonic mechanism between the processes of appearance and death of tillers as a way of keeping the tiller density stable under a certain condition of environment and management (Da Silva et al., 2008). It is possible, therefore, that according to the lower appearance rate of basal tillers from 31 to 60 days of deferment, the Piata palisade grass kept its mortality and survival rates of basal tillers stable in order to avoid an acute reduction of tiller density. This compensation did not occur in aerial tillers, which usually present higher mortality rate and lower survival rate with the advance of the period of deferment. These results indicate that aerial tillers are the first ones to be penalized in situations in which there is an elevated intraspecific competition for light inside the sward. The tillers of a forage plant present a physiological link with each other (Langer, 1963). When emerging from a basal or lateral bud, the tiller is entirely supplied by the tiller which gave its origin (Robson et al., 1988). Under conditions of elevated competition for light, the photoassimilates (carbon) produced during photosynthesis are preferably allocated to the existent tillers in relation the axillary buds or smaller tillers. Thus, although the aerial tillers are located in the 
superior part of the sward, i.e., in a region where there is a smaller competition for light, they do not have priority during the assimilate sharing when compared with basal tillers.

The adjustments in the rates of appearance, mortality, and survival were not enough to keep the tiller density stable in periods of deferment over 30 days. This fact may be inferred by the negative balance between appearance and mortality of tillers in the periods of deferment from 31 to 60,61 to 90 and from 91 to 120 days (Table 5), which demonstrates that the mortality rate was higher than the appearance rate of aerial and basal tillers.

The similarity of the values of mortality of basal tillers during the period of deferment (Table 5) may be justified by factors that possibly worked in distinct periods. In the beginning of the period of deferment (from 1 to 30 days), it is possible that the elimination of the apical meristem was the main factor to determine the tiller mortality due to the mechanical cut performed. Nevertheless, from the 31 days of deferment, the high leaf index and higher light interception by the sward (Table 2), coupled with the more restrictive climatic conditions were probably the main causes of the tiller mortality.

The joint analysis of the effects of the variations in the rates of appearance and mortality of tillers may be done by the stability index of the tiller density (Bahmani et al., 2003). Overall, values lower than 1.0 indicate that the survival and appearance of new tillers are not enough to compensate the rates of mortality, and, therefore, the density tends to decrease. Values higher than 1.0 suggest an inverse situation. Values near 1.0 indicate a stable tiller density, in which the number of tillers practically does not vary, despite being a result of a dynamic balance (Bahmani et al., 2003).

The stability index of basal and aerial tillers of deferred Piata palisade grass was higher than 1.0 only in the period from 1 to 30 days (Table 5), demonstrating that there was a reduction in the tiller density in longer periods of deferment. In fact, Santos et al. (2010) verified that longer periods of deferment resulted in a decrease in the number of vegetative tillers on pastures of Brachiaria decumbens cv. Basilisk. It is possible that vegetative and smaller tillers were shaded and killed because of the competition for light against older tillers (longer size) during the period of deferment. In a shading situation, a greater quantity of assimilates is allocated for the growth of existent tillers over new ones (Robson et al., 1988).

It is worth remarking that the elevated values of balance between appearance and mortality of tillers, as well as stability index, either in basal tillers or in aerial tillers recorded in the period from 1 to 30 days, increased the density of basal and aerial tillers in $62 \%$ and $311 \%$ respectively (Table 5). Throughout the period of deferment, this tiller density was not mantained mainly due to the climatic conditions restrictive to the plant growth (Table 1) and to the elevation in the competition for light inside the sward (Table 2).

The negative balance between the rates of appearance and mortality of tillers of the deferred Piata palisade grass for a longer period indicates that this management strategy could jeopardize the persistence of this forage plant. Nevertheless, in a study conducted by Santana (2011), it was verified that pastures of Brachiaria decumbens cv. Basilisk deferred during the winter presented high balances between the appearance and mortality of tillers in the following season (spring) especially in the ones managed with lower height in the beginning of the period of deferment. These results demonstrate that the plants from tropical climates increase the tiller density in the spring when well managed in spite of the deleterious effect of the period of deferment on the tillering.

The flowering rate of basal tillers was greater in the period from 1 to 30 days, reducing with the advance of the experimental period. The flowering rate of aerial tillers did not vary (Table 5). The Piata palisade grass presents flowering in the summer time (January - February) (Valle et al., 2010), a fact that determined the reduction in the flowering rate with the advance in the period of deferment.

Considering that during the period of deferment there is a negative balance between the appearance and mortality of tillers (Table 5) and that there is an increase of biomass in the pasture (Santos et al., 2010), it is possible to infer that the increase in the forage mass in deferred pastures for a longer period is due to the elevation in the weight of the tillers. This compensatory mechanism between the number and weight of tillers that occurs on the pasture is called size/tiller density compensation, and it has been reported for forage of tropical climate and of the genera Cynodon (Sbrissia et al., 2003) and Brachiaria (Santos et al., 2011).

The Piata palisade grass deferred with low initial height intercepted a smaller quantity of light because of its lower leaf area index and higher angle in the leaf (more vertical orientation of the sward) in this condition (Table 2). Lower cuts remove higher quantity of forage, which reduces the initial regrowth rate of the pasture (Brougham, 1956) due to the reduced surface of interception of incident light (leaves), associated with its limited photosynthetic capacity after defoliation (Parsons \& Penning, 1988; Braga et al., 2009). Additionally, the lower participation of the leaves in relation to the stems and the smaller length of the remaining leaf blades after defoliation favor a more vertical disposition of 
the sward (higher leaf angle) (Sousa, 2009). Besides, plants with more erect leaves intercept less light with the same leaf area index in comparison with the ones with more horizontal leaves (Bernardes, 1987). These results indicate alterations in the sward structure in response to the management adopted in the beginning of the deferment period.

On the other hand, the descriptive characteristics of the tiller density dynamics were not influenced $(\mathrm{P}>0.05)$ by the height of the pasture in the beginning of the deferment period (Table 4). This way, the hypothesis that the reduction of the height in the pasture in the beginning of this period stimulates the tillering in the deferred pasture was not confirmed despite the occurrence of higher light penetration inside the sward, which may be found from the results of light interception by the sward (Table 2). In this context, the restrictive climatic conditions to the plant growth at the end of the fall and during the winter (Table 1), periods in which the Piata palisade grass kept deferred, probably had preponderant inhibitory effect on the tillering, so they cancelled the possible benefits in the reduction of the pasture height on its tillering.

It is worth noting that even without effect of the pasture initial height on the tillering of the deferred Piata palisade grass (Table 4), there are other benefits associated with the reduction of the initial height of the pasture to be deferred, such as reduction of the falling index and forage production with a greater participation of green leaves and lower percentage of dead stem in the winter (Silva, 2011). Furthermore, pastures deferred at lower initial heights and used in the winter present more vigorous regrowth during the spring (Santana, 2011).

\section{Conclusions}

The reduction in the initial height of the Piata palisade grass improves the luminous environment in the sward, but it does not stimulate its tillering during the period of deferment. From the beginning to the end of the period of deferment, there is greater shading within the sward, so the tiller appearance of the Piata palisade grass is reduced.

\section{References}

BAHMANI, I.; THOM, E.R.; MATTHEW, C. et al. Tiller dynamics of perennial ryegrass cultivars derived from different New Zealand ecotypes: effects of cultivar, season, nitrogen fertilizer, and irrigation. Australian Journal of Agricultural Research, v.54, p.803-817, 2003

BRAGA, G.J.; De MELlO, A.C.L.; PEDREIRA, C.G.S. et al. Fotossíntese e taxa diária de produção de forragem em pastagens de capim-tanzânia sob lotação intermitente. Pesquisa Agropecuária Brasileira, v.44, p.84-91, 2009.
BROUGHAM, R.W. Effects of intensity of defoliation on regrowth of pasture. Australian Journal of Agricultural Research, v.7, p.377-387, 1956.

BERNARDES, M.S. Fotossíntese no dossel das plantas cultivadas. In: CASTRO, P.R.C.; FERREIRA, S.O.; YAMADA, T. (Eds.). Ecofisiologia da produção agrícola. Piracicaba: Associação Brasileira de Pesquisa de Potassa e do Fosfato, 1987. p.13-48.

BIRCHAM, J.S.; HODGSON, J. The influence of sward condition on rates of herbage growth and senescence in mixed swards under continuous stocking management. Grass and Forage Science, v.38, p.323-331, 1983.

DA SILVA, S.C. Understanding the dynamics of herbage accumulation in tropical grass species: the basis for planning efficient grazing management pratices. In: SIMPÓSIO EM ECOFISIOLOGIA DAS PASTAGENS E ECOLOGIA DO PASTEJO, 2004, Curitiba. Anais... Curitiba: UFPR, 2004. v.2 (CD-ROM).

DA SILVA, S.C.; NASCIMENTO JÚNIOR, D.; SBRISSIA, A.F. et al. Dinâmica de população de plantas forrageiras em pastagens. In: SIMPÓSIO SOBRE MANEJO ESTRATÉGICO DA PASTAGEM, 4., 2008, Viçosa, MG. Anais... Viçosa, MG: UFV, 2008. p.75-99.

DEREGIBUS, V.A.; SANCHEZ, R.A.; CASAL, J.J. Effects of light quality on tiller production in Lolium spp. Plant Physiology, v.27, p.900-912, 1983.

DURU, M.; DUCROCQ, H. Growth and senescence of the successive grass leaves o a tiller ontogenic development and effect of temperature. Annals of Botany, v.85, p.635-643, 2000.

EMPRESA BRASILEIRA DE PESQUISA AGROPECUÁRIA EMBRAPA. Serviço Nacional de Levantamento e Conservação de Solos. Sistema brasileiro de classificação de solos. 2.ed. Rio de Janeiro: Embrapa Solos, 2006. 306p.

EMBRAPA GADO DE CORTE. Piatã: cultivar de Brachiaria brizantha. Campo Grande, MS, [2007]. Available at: $<\mathrm{http} / / \mathrm{www}$. cnpgc.embrapa.br/produtoseservicos/pdf/piata.pdf $>$ Accessed on: May 19, 2012.

HODGSON, J. Grazing management - science into practice. New York: John Wiley \& Sons, Inc., Longman Scientific \& Technical. 1990. 203p.

KÖPEN, W. Climatologia. Buenos Aires: Gráfica Panamericana, 1948. 478p.

LANGER, R.H.M. Tillering in herbage grass. A review. Herbage Abstracts, v.33, p.141-148, 1963

LEMAIRE, G.; CHAPMAN, D. Tissue flows in grazed plant communities. In: HODGSON, J.; ILLIUS, A.W. (Eds.). The ecology and management of grazing systems. Wallingford: $C A B$ International, 1996. p.3-36.

MATTHEW, C.; ASSUERO, S.G.; BLACK, C.K. et al. Tiller dynamics of grazed swards. In: LEMAIRE, G.; HODGSON, J., MORAES, A. et al. (Eds.). Grassland ecophysiology and grazing ecology. Wallingford: CAB International, 2000. p.127-150.

PARSONS, A.J.; PENNING, P.D. The effect of the duration of regrowth on photosynthesis, leaf death and the average rate of growth in a rotationally grazed sward. Grass and Forage Science, v.43, p. 15-27, 1988 .

ROBSON, M.J.; RYLE, G.J.A.; WOLEDGE, J. The grass plants: its form and function. In: JONES, M.B.; LAZENBY, A. (Eds.). The grass crop: the physiological basis of production. London: Chapman and Hall, 1988. p.25-83.

SANTANA, S.S. Rebrotação na primavera de pastos de capimbraquiária diferidos com quatro alturas. 2011. 83f. Dissertação (Mestrado em Zootecnia) - Universidade Federal de Viçosa, Viçosa, MG.

SANTOS, M.E.R.; FONSECA, D.M.; BALBINO, E.M. et al. Caracterização dos perfilhos em pastos de capim-braquiária diferidos e adubados com nitrogênio. Revista Brasileira de Zootecnia, v.38, p.643-649, 2009.

SANTOS, M.E.R.; FONSECA, D.M.; GOMES, V.M. et al. Estrutura do capim-braquiária durante o diferimento da pastagem. Acta Scientiarum. Animal Science, v.32, p.139-145, 2010.

SANTOS, M.E.R.; FONSECA, D.M.; PIMENTEL, R.M. et al. Número e peso de perfilhos no pasto de capim-braquiária sob 
lotação contínua. Acta Scientiarum. Animal Science, v.33, p.131-136, 2011.

SBRISSIA, A.F.; DA SILVA, S.; MATTHEW, C. et al. Tiller size/ density compensation in grazed Tifton 85 bermudagrass wards. Pesquisa Agropecuária Brasileira, v.38, p.1459-1468, 2003.

SILVA, A.A.S. Altura inicial e adubação nitrogenada em pastos diferidos de capim-braquiária. 2011. 50f. Dissertação (Mestrado em Zootecnia) - Universidade Federal de Viçosa, Viçosa, MG.
SOUSA, B.M.L. Morfogênese e características estruturais dos capins Andropógon e Xaraés submetidos a três alturas de corte. 2009. 108f. Dissertação (Mestrado em Zootecnia) - Universidade Federal de Viçosa, Viçosa, MG.

VALLE, C.B.; MACEDO, M.C.M.; EUCLIDES, V.P.B. et al. Gênero Brachiaria. In: FONSECA, D.M.; MARTUSCELLO, J.A. (Eds.). Plantas forrageiras. Viçosa, MG: UFV, 2010. p.197-219. 